\title{
Ornithine Decarboxylase
}

National Cancer Institute

\section{Source}

National Cancer Institute. Ornithine Decarboxylase. NCI Thesaurus. Code C38931.

Ornithine decarboxylase (461 aa, $\sim 51 \mathrm{kDa}$ ) is encoded by the human ODC1 gene. This protein plays a role in the biosynthesis of polyamines. 